\title{
Endometrial cancer: a genetic point of view
}

\author{
Bianca Bianco $^{1 \wedge}$, Caio Parente Barbosa ${ }^{1} \wedge$, Camila Martins Trevisan $^{2} \wedge$, Antonio Simone Laganà ${ }^{\wedge}$, \\ Erik Montagna $^{2} \wedge$
}

${ }^{1}$ Discipline of Sexual and Reproductive Health and Populational Genetics, Department of Collective Health, Santo André, Brazil; ${ }^{2}$ Postgraduate Program in Health Sciences, Faculdade de Medicina do ABC, Santo André, Brazil; ${ }^{3}$ Department of Obstetrics and Gynecology, "Filippo Del Ponte" Hospital, University of Insubria, Varese, Italy Contributions: (I) Conception and design: B Bianco, AS Laganà, E Montagna; (II) Administrative support: None; (III) Provision of study materials or patients: None; (IV) Collection and assembly of data: CM Trevisan, E Montagna; (V) Data analysis and interpretation: All authors; (VI) Manuscript writing: All authors; (VII) Final approval of manuscript: All authors.

Correspondence to: Bianca Bianco. Faculdade de Medicina do ABC - Av. Lauro Gomes, 2000, Santo André/SP, CEP 09060-870, Brazil. Email: bianca.bianco@fmabc.br.

Background: Endometrial cancer is the fourth most frequent gynecological cancer and the most frequent type of uterine cancer. There is an increase in the incidence and mortality of uterine cancers in the past few decades, and there are no well-established screening programs for endometrial cancer currently. Most endometrial cancers arise through the interplay of familial, genetic, and lifestyle factors. Although a number of genetic factors modify endometrial cancer susceptibility, they are not of standard use in the clinical assessment of prognosis. We conducted a comprehensive systematic literature review to provide an overview of the relationship between genetic factors and risk for endometrial cancer.

Methods: MEDLINE and EMBASE databases were searched for studies between January 2010 to March 2020 reporting the genes associated with endometrial cancer.

Results: Through the selection process, we retrieved 186 studies comprising 329 genes identified using several molecular methodologies in all human chromosomes and in mitochondrial DNA. Endometrial cancer exhibits a molecular complexity and heterogeneity coherent with its clinical and histologic variability. Improved characterization of molecular alterations of each histological type provides relevant information about the prognosis and potential response to new therapies.

Conclusions: The current challenge is the integration of clinicopathologic and molecular factors to improve the diagnosis, prognosis, and treatment of endometrial cancer.

Keywords: Endometrial cancer; genetic; systematic review; genetic marker

Submitted Jun 15, 2020. Accepted for publication Nov 03, 2020.

doi: $10.21037 /$ tcr-20-2334

View this article at: http://dx.doi.org/10.21037/tcr-20-2334

\section{Introduction}

Endometrial cancer is globally the fourth most frequent gynecological cancer and the most frequent type of uterine cancer, with the highest rates observed in developed countries. There is a lifetime estimated occurrence of endometrial cancer in $3 \%$ of women (1). In Brazil, the mortality due to endometrial cancer in 2015 was 1,454 , and the expected incidence of the cancer is 6,540 in 2020 (2). In the United States, the incidence of endometrial cancer was 63,230 and the mortality was 11,350 in 2018 , with uterine cancer being the fourth most common cancer in women and the fifth leading cause of cancer deaths in the county $(1,3)$.

\footnotetext{
^ ORCID: Bianca Bianco, 0000-0001-8669-3562; Caio Parente Barbosa, 0000-0002-2922-0264; Camila Martins Trevisan, 0000-0003-21255566; Antonio Simone Laganà, 0000-0003-1543-2802; Erik Montagna, 0000-0001-6834-0261.
} 
Endometrial cancer has a heterogeneous pathophysiology, encompassing many histological types, microscopical features, pathogenesis, behaviors, and prognosis. Endometrial cancers have been classified into two groups: type I is mostly low-grade endometrioid tumors developing from glandular cells in the lining of the endometrium, expressing high levels of estrogen receptor $\alpha$ with a favorable overall prognosis. They represent $80-90 \%$ of the endometrial cancer incidence and $40 \%$ of the cancer mortality. Type II endometrial tumors mainly include serous papillary or clear cell histology, are non-estrogen dependent, and exhibit a more aggressive clinical course with poor prognosis (4-9). The nine different subtypes of endometrial cancer according to a recently updated classification by WHO (10) are mucinous carcinoma, endometrioid carcinoma, serous carcinoma, serous endometrial intraepithelial carcinoma, clear cell carcinoma, neuroendocrine tumor, mixed cell adenocarcinoma, undifferentiated carcinoma, and dedifferentiated carcinoma. However, endometrioid carcinomas and serous carcinoma are together responsible for $85 \%$ and $3-10 \%$ of the endometrial cancer cases, respectively (11). Endometrioid carcinomas are regarded as the prototypical type I tumor, whereas serous carcinomas are regarded as the prototypical type II tumors (12).

Rates of uterine cancers have increased by $21 \%$ during the past decade with increased mortality, similar to the rates in the early 1980s. This increase may be attributed to longer life expectancy, increased rates of obesity, and shifts in female reproductive patterns $(13,14)$. Recently, increased incidence has been reported in low-middle income countries, such as Brazil and South Africa (14).

Currently, there are no well-established screening programs for endometrial cancer, and full hysterectomy is the most widely used and effective treatment for early-stage tumors (15). The risk assessment for endometrial carcinoma is inaccurate and relies on less reproducible histological examinations $(16,17)$. Most patients receive a diagnosis in the early stages (I/II) owing to abnormal vaginal bleeding, observed in $94 \%$ of the cases (18). The patients show improved prognosis after surgery alone, with 5- and 10-year survival rates of $95 \%$ and $77 \%$, respectively. However, diagnosis in late stages (IV) results in a drastic reduction of survival, with the 5 -year survival rate being only $14 \%(19,20)$.

Several risk factors such as obesity, physical inactivity, excess exogenous estrogen, and insulin resistance are associated with increased risk of endometrial cancer (21). Women with a family history of endometrial cancer have approximately a 2 -fold increase in the risk of developing the disease, with heritability between $27 \%$ and $52 \%(9,22,23)$. A prospective study of 203,691 twins (monozygotic and samesex dizygotic) from Nordic countries revealed a cumulative cancer incidence of $32 \%$. In a median 32 years of followup, the authors observed a significant overall familial risk for cancer and specific types of cancer, including uterine cancers (27\%; 95\% CI, 11-43\%) (23).

In addition, approximately $3-5 \%$ of endometrial cancers occur in women with Lynch syndrome, an autosomal dominant hereditary predisposition to cancer, where patients have an increased risk of multiple cancers, including gastric, colorectal, ovarian, and endometrial cancers, during their lifetime. Lynch syndrome is caused by variations in the MLH1, MLH3, MSH2, MSH6, PMS2, TGFBR2, or EPCAM genes (24). The Society of Gynecologic Oncology since 2014 recommends a deep screening for Lynch syndrome in every woman diagnosed with endometrial cancer (25). Additionally, the much rarer autosomal dominant Cowden syndrome substantially increases the risk of endometrial cancer. Cowden syndrome is a cancer predisposition syndrome caused by pathogenic variants in PTEN, with affected patients having an increased risk of breast, thyroid, renal, colorectal, and endometrial cancers and malignant melanoma (26). Carriers of BRCA1 mutations may also have an increased risk of serous endometrial cancer (20).

Despite the involvement of genetic factors in the risk of endometrial cancer, they are not incorporated in the standard clinical procedures for prognosis assessment. Currently, variables adopted for risk stratification comprise stage, lymph node involvement, depth of myometrial invasion, histology, and grade (27).

The identification of biomarkers and their relationship with the risk factors are necessary for the improvement in risk stratification and early detection of endometrial cancers in view of the rise in disease incidence and mortality. We conducted a comprehensive systematic review of the literature to provide an overview of the associations between genetic factors and risk of endometrial cancer. We present the following article in accordance with the PRISMA reporting checklist (available at http://dx. doi. org/10. 21037/tcr-20-2334).

\section{Methods}

\section{Search strategy}

The systematic review followed the Preferred Reporting 


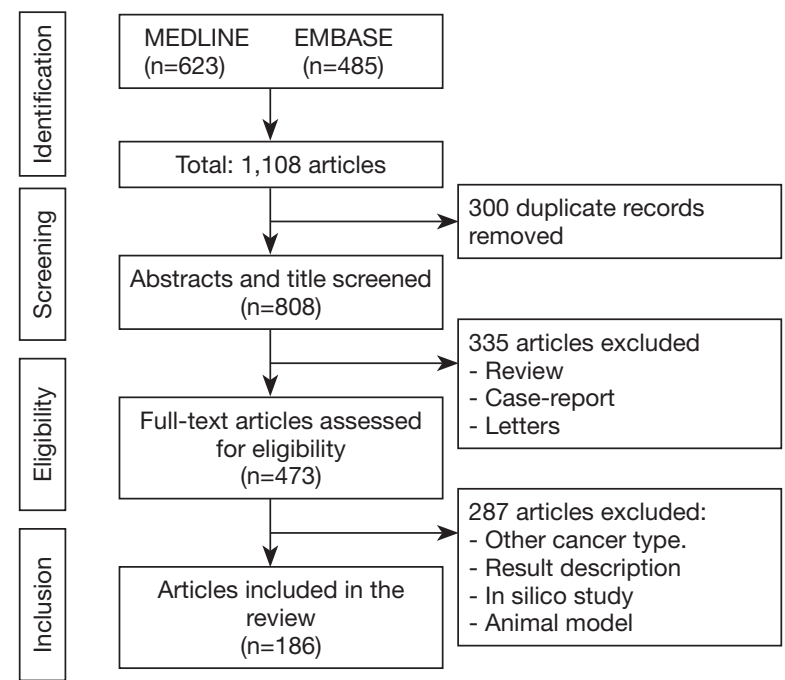

Figure 1 Flow diagram of the included studies.

Items for Systematic Reviews and Meta-Analyses (PRISMA) recommendations (28). The search was performed in March 2020. Databases searched were Embase and MEDLINE with time spam restrictions from 2010 to 2020 aiming to studies reporting genes and genetic polymorphisms associated to endometrial cancer. Terms included MeSH terms and words in both title and abstract comprising "Endometrial Neoplasms", "Endometrial Cancer", "Polymorphism, Genetic", "Genetic Profile", "Genetic Markers" for MEDLINE. Terms for Embase were "endometrium tumor", "endometrium cancer", "genetic marker", "single nucleotide polymorphism" and related terms. No language restrictions were applied.

\section{Eligibility criteria}

Studies were selected by three independent investigators in a prepiloted form, with disagreements resolved by a fourth member. The criteria for full-text evaluation were if they were primary studies reporting genes involved in the pathophysiology of the endometrial cancer disregarding the study design or technique used for detection. Study outcome was the detection of alterations in genes related to endometrial cancer reported.

\section{Data extraction and synthesis}

Data extracted from each study were gene, chromosome location, year of publication, first author, type of study, country of the study and doi number.

\section{Results}

A total of 483 articles were evaluated and 186 (the complete list of references of the summary of evidence is available in Supplementary file 1) were retrieved in the selection process, comprising 329 genes that were studied in all human chromosomes and in mitochondrial DNA by several molecular methodologies (Table 1). The PRISMA flow of included studies is presented in Figure 1. The complete summary of findings is available in the online table (Table S1).

\section{Evidence retrieved}

It has become well known in the past two decades that endometrial cancers present the highest molecular complexity among common tumor types, and its mechanistic heterogeneity is conformable with histologic and clinical variability (29).

Endometrial carcinomas have distinguishing molecular features. The most frequently mutated genes in endometrioid carcinomas are PTEN (>77\%), PIK3CA (53\%), PIK3R1 (37\%), CTNNB1 (36\%), ARID1A (35\%), K-RAS (24\%), CTCF (20\%), RPL22 (12\%), TP53 (11\%), FGFR2 (11\%), and ARIDSB (11\%). The most frequently mutated genes in serous carcinomas are TP53 (80-90\%), PIK3CA (41.9\%), PPP2R1A (36.6\%), FBXW7 (30.2\%), CHD4 (16.3\%), CSMD3 (11.6\%), and COLA11 (11.6\%), along with loss of heterozygosity (LOH) on many chromosomes and several molecular changes (STK15, 
Table 1 Genes studied in endometrial cancer

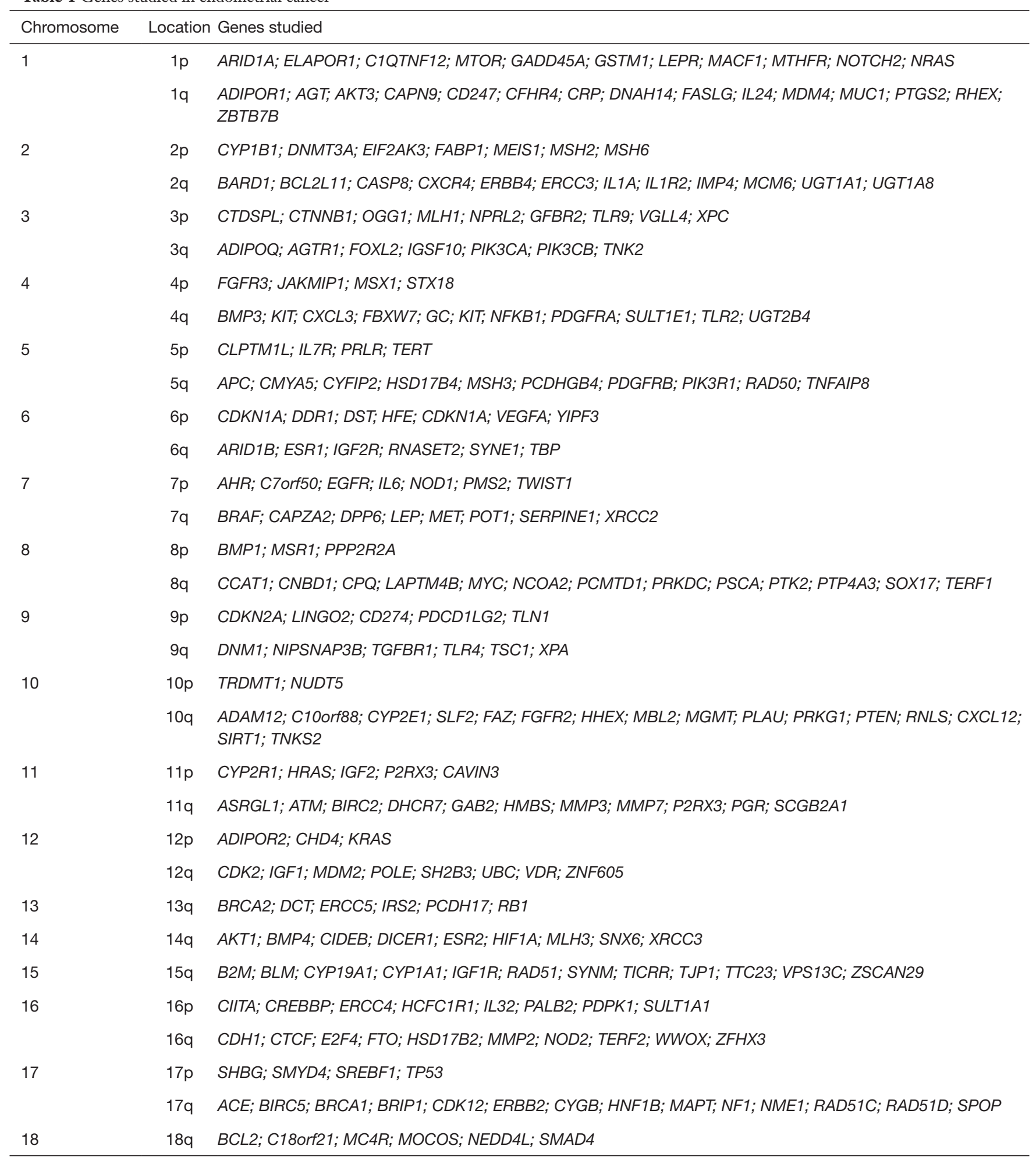

Table 1 (continued) 
Table 1 (continued)

\begin{tabular}{lcl}
\hline Chromosome & Location & Genes studied \\
\hline 19 & $19 \mathrm{p}$ & MUC16; DNMT1; INSR; KEAP1; NFIC; PIK3R2; RETN; SMARCA4 \\
& $19 \mathrm{q}$ & $\begin{array}{l}\text { AKT2; APOE; BAX; CCNE1; DYRK1B; ERCC1; ERCC2; LIG1; PAK4; NOP53; PLAUR; POLD1; PPP2R1A; TGFB1; } \\
\text { URI1; XRCC1 }\end{array}$ \\
20 & $20 \mathrm{p}$ & BMP2 \\
& $20 \mathrm{q}$ & ASXL1; AURKA; BMP7; DNMT3B; EYA2; MMP9; SNAI1; ZNF217 \\
21 & $21 \mathrm{q}$ & GABPA; TFF3 \\
22 & $22 \mathrm{q}$ & BIK; CBY1; CHEK2; CHEK2; COMT; GSTT1 \\
$\mathrm{X}$ & $\mathrm{Xp}$ & ATP6AP2; FOXP3 \\
& $\mathrm{Xq}$ & ARMCX4; DACH2; HPRT1; TAF1; XIST \\
& - & MT-CO2; MT-ND1 \\
\hline
\end{tabular}

p16, E-cadherin, and C-erbB2) (3,11,30,31). Moreover, microsatellite instability (MSI) is detected in $25-40 \%$ of type I carcinomas, although it is rare in type II carcinomas $(<5 \%)$. TP53 is mutated in more than $90 \%$ of type II carcinomas and in $11 \%$ of type I carcinomas. From the pathogenetic viewpoint, type I versus type II classification is interesting, despite the challenging application to clinical practice (11).

A recent characterization of 373 endometrial carcinomas using array- and sequencing-based technologies, through an integrated analysis of genomic, transcriptomic, and proteomic data by The Cancer Genome Atlas (TCGA) provided comprehensive information about pathway alterations and molecular mechanisms, describing four different molecular subgroups. Polymerase epsilon (POLE)-mutated subgroup with very high mutation rates $\left(232 \times 10^{6}\right.$ mutations/Mb) (ultramutated) is associated with good prognosis and account for $7-10 \%$ of endometrioid carcinomas. MSI subgroup with frequent hypermethylation of MLH1 promoter and elevated mutation rates $(18 \times$ $10^{6}$ mutations/Mb) account for $28-30 \%$ of endometrioid carcinomas. Low copy number alterations subgroup with low mutation rate $\left(2.9 \times 10^{6}\right.$ mutations $\left./ \mathrm{Mb}\right)$ represents $39 \%$ of endometrioid carcinomas, and high copy number subgroup (serous-like) with low mutation rate $(2.3 \times$ $10^{6}$ mutations/Mb) but frequent TP53 mutations with worse prognosis represents serous carcinoma (94\%). The candidate driver or pathogenic genes varied in all four subgroups, with 190 genes in the POLE subgroup, 21 in the
MSI subgroup, 16 in the low copy number subgroup, and 8 in the high copy number subgroup $(3,11,12)$ (Table 2).

Endometrioid carcinomas were present in all four subgroups. Endometrioid carcinoma is generally characterized by frequent derangements of the PI3KPTEN-AKT-mTOR, RAS-MEK-ERK, and canonical WNT- $\beta$-catenin pathways. Endometrial cancer presents more mutations than any other tumor type studied thus far in the PI3K/AKT pathway by TCGA. The PI3K-PTENAKT-mTOR signal transduction pathway regulates cell growth and survival, synthesis of specific proteins, and metabolism. The RAS-RAF-MEK-ERK pathway plays a central role in regulation of cell proliferation, cell survival, and differentiation, is activated by $K R A S$ mutations in endometrioid carcinoma, and can co-occur with alterations in PTEN, PIK3CA, and/or PIK3R1. The canonical WNT- $\beta$-catenin pathway regulates several cellular processes, which are constitutively activated in endometrioid carcinomas through gain-of-function mutations in CTNNB1 ( $\beta$-catenin) (12). In addition, DNA mismatch repair (MMR) deficiency, a characteristic of $30 \%$ endometrioid cancers, is a major pathway enabling genomic instability in human cancers. Nonfunctional MMR leads to accumulation of insertion/ deletion mutations at repetitive DNA stretches, such as microsatellites, and are, therefore, present with the MSI phenotype (32,33). The consequence of epigenetic silencing caused by promoter hypermethylation of $M L H 1$ leads to MSI in sporadic endometrioid carcinomas. 
Table 2 The most frequently altered genes of endometrial cancer subgroups

\begin{tabular}{|c|c|c|}
\hline TCGA subgroup & Mutation profile & Frequency \\
\hline \multirow[t]{7}{*}{ POLE ultramutated } & PTEN & $94 \%$ \\
\hline & FBXW7 & $82 \%$ \\
\hline & $A R I D 1 A$ & $76 \%$ \\
\hline & PIK $3 C A$ & $71 \%$ \\
\hline & PIK3R1 & $65 \%$ \\
\hline & KRAS & $53 \%$ \\
\hline & $A R I D 5 B$ & $47 \%$ \\
\hline \multirow{6}{*}{$\begin{array}{l}\text { Microsatellite instability } \\
\text { hypermutated }\end{array}$} & PTEN & $88 \%$ \\
\hline & PIКЗСA & $54 \%$ \\
\hline & KRAS & $35 \%$ \\
\hline & PIK3R1 & $40 \%$ \\
\hline & $A R I D 1 A$ & $37 \%$ \\
\hline & RPL22 & $33 \%$ \\
\hline \multirow[t]{5}{*}{ Copy number low } & PTEN & $77 \%$ \\
\hline & PIKЗCA & $53 \%$ \\
\hline & CTNNB1 & $52 \%$ \\
\hline & $A R I D 1 A$ & $42 \%$ \\
\hline & PIK3R1 & $33 \%$ \\
\hline \multirow[t]{3}{*}{ Copy number high } & TP53 & $92 \%$ \\
\hline & PIКЗCA & $47 \%$ \\
\hline & $P P P 2 R 1 A$ & $22 \%$ \\
\hline
\end{tabular}

TCGA, The Cancer Genome Atlas.

This results in the accumulation of somatic mutations at nucleotide repeats throughout the genome by defective MMR. Recently, ATR, CTCF, FAK1, RNF43, and RPL22 were indicated as drivers of the sustained pathogenic frameshift mutations at mononucleotide repeats in MSI-positive endometrioid carcinomas. Other known mechanisms of genomic instability in endometrioid carcinomas are somatic mutations of the exonuclease domain of POLE (12).

All types of serous carcinomas, except for a single tumor, belong to the high copy number subgroup in the TCGA classification. Mutations and/or dysregulation of TP53 or p53 are the most frequent molecular aberrations. Somatic mutations in PPP2R1A, FBXW7, SPOP, CHD4, and TAF1 are also involved in the serous carcinoma pathogenesis.
In addition, overexpression or amplification of CCNE1, $E R B B 2, M Y C$, synuclein- $\gamma$, and p16 is observed $(12,34,35)$.

Endometrial cancer risk may be influenced by common low-penetrance variants, such as single nucleotide variants ( $\mathrm{SNVs}$, in genes involved in cell survival, estrogen metabolism, and transcriptional control. A systematic review by Bafligil et al. (36) revealed that SNVs in $H N F 1 B$ (rs11263761), KLF (rs7981863), EIF2AK (rs937213), CYP19A1 (rs17601876), SOX4 (rs1740828), and MYC (rs4733613, rs35286446, rs139584729) are strongly associated with endometrial cancer.

Recently, Benati et al. (37) investigated the relative length of the telomere in cell-free DNA (cfDNA) of patients with endometrioid endometrial cancer and healthy controls. They showed that the relative telomere length in cfDNA was significantly lower in cancer patients than in healthy controls, with a diagnostic accuracy of 0.87 (95\% CI: $0.79-0.95, \mathrm{P}<0.0001)$ and $80.0 \%$ (95\% CI: $64.35-90.95 \%)$ sensitivity and $80.65 \%$ (95\% CI: $62.53-92.55 \%)$ specificity for endometrial cancer. The authors also highlighted that despite the reduced relative length of telomere in cfDNA is not specific for endometrial cancer, it might be useful as an early diagnostic tool for endometrial cancer in highrisk patients, such as those with endometrial hyperplasia, particularly in young patients that may benefit from a fertility-sparing approach.

Providing strategies for translation of genomic profile to clinical practice is garnering interest, especially the use of methods often available in the pathology toolbox $(11,38,39)$. Stello et al. (40) aimed to confirm the prognostic potential of the TCGA subgroups from two large randomized trial populations comprising 834 early-stage endometrioid endometrial carcinomas (PORTEC-1 and -2) with longterm follow-up. They confirmed the effect of the four molecular subgroups on prognosis initially proposed by the TCGA. The substitution of markers for molecular analysis methods applicable clinically was used and proved feasible in $>96 \%$ of patients with endometrioid endometrial carcinoma. Integration of well-established clinicopathological factors with prognostic molecular alterations resulted in a robust risk assessment. Approximately $15 \%$ patients with a markedly unfavorable prognosis and $50 \%$ patients with a favorable prognosis could be identified. Another way for clinical translation may be the development of polygenic risk scores for endometrial cancer. Therefore, a major research priority is the expansion of endometrial cancer genomic profile to non-European populations enabling comparable polygenic risk scores of many ethnic groups (9). 
Casarin et al. (2020) (41) investigated the potential role of glandular cells as a prognostic factor in cervical cytology in the preoperative identification and assessment of endometrial cancer. They observed no differences in the 5 -year disease-free survival and overall survival between the normal cytology and glandular cell groups. However, cervical stromal invasion and presence of glandular cells increased the risk of local recurrence in endometrial cancer.

In addition to the genetic factors, the available data showed that the endocannabinoid system plays an important role in the development and progression of gynecological malignancies. The activation of cannabinoid receptor type 1 (CB1R), a G-protein coupled receptor present in the central nervous system and peripheral tissues such as the ovaries and uterus, can regulate cell proliferation, differentiation, and death. Moreover, cannabinoid receptor activation can inhibit cancer cell invasion through indirect downregulation of metalloproteinase (MMP2) expression and activity. Endocannabinoids also play a role in the inhibition of neoangiogenesis by decreasing the production of proangiogenic factors and/or by directly modulating endothelial cells, decreasing the expression of vascular endothelial growth factor (VEGF) and VEGF receptor (VEGF-R). The cannabinoid receptor type 2 (CB2R) is expressed the most in endometrial cancer biopsies and has a potential role in the control of cancer cell growth through the regulation of mitochondrial function and cell apoptosis $(42,43)$.

Despite the availability of guidelines for assessment, genetic testing, and genetic counseling of patients diagnosed with endometrial cancer, these services are not offered equitably or consistently (44-47). Genetic counseling is a process to support individuals and families affected by or are at risk of genetic or hereditary diseases. Trained healthcare personnel provide counseling, and the assessment is based on a combination of the personal medical and family history. The aim of the counseling is to help individuals understand and adapt to the clinical, psychosocial, economical, and ethical issues raised during the diagnostic process, with a focus on disease information, inheritance, genetic testing, management options, career, and family plan, as well as management of affected or at-risk relatives (47-50).

Hinchcliff et al. (44) summarized the literature on genetic counseling and genetic testing of patients affected by gynecologic cancers and observed that a small proportion of studies provided assessment on guideline compliance or tumor screening completion rate [immunohistochemistry
(IHC) and/or MSI], genetic counseling, or genetic testing among patients diagnosed with endometrial cancer in the United States. In addition, the authors draw attention to the variability of tumor screening among hospitals and also among healthcare providers ordering the testing, interpretation of findings, and patient triage to genetics services.

Although endometrial cancer is mostly diagnosed in women over the age of 60 years, approximately $5 \%$ of all women diagnosed are of reproductive age (51), and the impairment of reproductive function, especially ovarian insufficiency, is one of the long-term consequences of cancer therapy. The American Society of Clinical Oncology (ASCO) and the American Society for Reproductive Medicine (ASRM) strongly recommend clinicians to inform patients about the potential loss of fertility and possibility of fertility preservation before chemotherapy and radiotherapy (52). Moreover, quality of life represents a relevant concern in patient care; together with potential secondary infertility, the side effects of cancer diagnosis and treatment can affect the physical, mental, and social wellbeing of patients leading to depression and anxiety (53).

Because of the diversity and complexity of the genetic counseling process, in-depth approaches on patient counseling by a team should be considered. An ideal counseling team should consist of clinicians including oncologist, surgeon, obstetrician gynecologist, psychologist and/or psychiatrist, medical geneticist, molecular diagnostic specialist, genetics nurses, and ancillary staff (42-44).

\section{Conclusions}

In summary, a combination of genomic characterization along with pathological diagnosis, genetic counseling and psychological support are pivotal in improving the prognostic assessment and clinical management of patients with endometrial cancer.

\section{Acknowledgments}

Funding: None.

\section{Footnote}

Provenance and Peer Review: This article was commissioned by the editorial office, Translational Cancer Research for 
the series "Endometrial Cancer". The article was sent for external peer review.

Reporting Checklist: The authors have completed the PRISMA reporting checklist. Available at http://dx. doi. org/10. 21037/tcr-20-2334

Conflicts of Interest: All authors have completed the ICMJE uniform disclosure form (available at http://dx. doi. org/10.21037/tcr-20-2334). The series "Endometrial Cancer" was commissioned by the editorial office without any funding or sponsorship. Dr. ASL served as the unpaid Guest Editor of the series, and serves as an unpaid editorial board member of Translational Cancer Research from Dec 2019 to Nov 2021. The other authors have no other conflicts of interest to declare.

Ethical Statement: The authors are accountable for all aspects of the work in ensuring that questions related to the accuracy or integrity of any part of the work are appropriately investigated and resolved.

Open Access Statement: This is an Open Access article distributed in accordance with the Creative Commons Attribution-NonCommercial-NoDerivs 4.0 International License (CC BY-NC-ND 4.0), which permits the noncommercial replication and distribution of the article with the strict proviso that no changes or edits are made and the original work is properly cited (including links to both the formal publication through the relevant DOI and the license). See: https://creativecommons.org/licenses/by-nc-nd/4.0/.

\section{References}

1. Alves M, Carreira I, Liberato P, et al. Identification of a 0.4 $\mathrm{Kb}$ deletion region in 10q26 associated with endometrial carcinoma. Oncol Rep 2010;23:519-22.

2. Ashton KA, Proietto A, Otton G, et al. Polymorphisms in genes of the steroid hormone biosynthesis and metabolism pathways and endometrial cancer risk. Cancer Epidemiol 2010;34:328-37.

3. Ashton KA, Proietto A, Otton G, et al. Toll-like receptor (TLR) and nucleosome-binding oligomerization domain (NOD) gene polymorphisms and endometrial cancer risk. BMC cancer 2010;10:382.

4. Bilbao C, Lara PC, Ramirez R, et al. Microsatellite instability predicts clinical outcome in radiation-treated endometrioid endometrial cancer. Int J Radiat Oncol Biol
Phys 2010;76:9-13.

5. Cayan F, Tok E, Aras-Ates N, et al. Insulin receptor substrate-2 gene polymorphism: is it associated with endometrial cancer? Gynecol Endocrinol 2010;26:378-82.

6. Dobrzycka B, Terlikowski SJ, Mazurek A, et al. Circulating free DNA, p53 antibody and mutations of KRAS gene in endometrial cancer. Int J Cancer 2010;127:612-21.

7. Gaudet MM, Yang HP, Bosquet JG, et al. No association between FTO or HHEX and endometrial cancer risk. Cancer Epidemiol Biomarkers Prev 2010;19:2106-9.

8. Ghasemi N, Karimi-Zarchi M, Mortazavi-Zadeh MR, et al. Evaluation of the frequency of TP53 gene codon 72 polymorphisms in Iranian patients with endometrial cancer. Cancer Genet Cytogenet 2010;196:167-70.

9. Janiec-Jankowska A, Konopka B, Goluda C, et al. TP53 mutations in endometrial cancers: relation to PTEN gene defects. Int J Gynecol Cancer 2010;20:196-202.

10. Lee E, Hsu C, Haiman CA, et al. Genetic variation in the progesterone receptor gene and risk of endometrial cancer: a haplotype-based approach. Carcinogenesis 2010;31:1392-9.

11. Low YL, Li Y, Humphreys K, et al. Multi-variant pathway association analysis reveals the importance of genetic determinants of estrogen metabolism in breast and endometrial cancer susceptibility. PLoS Genet 2010;6:e1001012.

12. Murayama-Hosokawa S, Oda K, Nakagawa S, et al. Genome-wide single-nucleotide polymorphism arrays in endometrial carcinomas associate extensive chromosomal instability with poor prognosis and unveil frequent chromosomal imbalances involved in the PI3-kinase pathway. Oncogene 2010;29:1897-908.

13. Prescott J, McGrath M, Lee IM, et al. Telomere length and genetic analyses in population-based studies of endometrial cancer risk. Cancer 2010;116:4275-82.

14. Sliwinski T, Sitarek P, Stetkiewicz T, et al. Polymorphism of the ERalpha and CYP1B1 genes in endometrial cancer in a Polish subpopulation. J Obstet Gynaecol Res 2010;36:311-7.

15. Terry K, McGrath M, Lee IM, et al. Genetic variation in CYP11A1 and StAR in relation to endometrial cancer risk. Gynecol Oncol 2010;117:255-9.

16. Wang PH, Yi YC, Tsai HT, et al. Significant association of genetic polymorphism of human nonmetastatic clone 23 type 1 gene with an increased risk of endometrial cancer. Gynecol Oncol 2010;119:70-5.

17. Yang HP, Gonzalez Bosquet J, Li Q, et al. Common genetic variation in the sex hormone metabolic pathway 
and endometrial cancer risk: pathway-based evaluation of candidate genes. Carcinogenesis 2010;31:827-33.

18. Yi YC, Chou PT, Chen LY, et al. Matrix metalloproteinase-7 (MMP-7) polymorphism is a risk factor for endometrial cancer susceptibility. Clin Chem Lab Med 2010;48:337-44.

19. Cheung LW, Hennessy BT, Li J, et al. High frequency of PIK3R1 and PIK3R2 mutations in endometrial cancer elucidates a novel mechanism for regulation of PTEN protein stability. Cancer Discov 2011;1:170-85.

20. Doherty JA, Weiss NS, Fish S, et al. Polymorphisms in nucleotide excision repair genes and endometrial cancer risk. Cancer Epidemiol Biomarkers Prev 2011;20:1873-82.

21. Hlavna M, Kohut L, Lipkova J, et al. Relationship of resistin levels with endometrial cancer risk. Neoplasma 2011;58:124-8.

22. Karageorgi S, McGrath M, Lee IM, et al. Polymorphisms in genes hydroxysteroid-dehydrogenase-17b type 2 and type 4 and endometrial cancer risk. Gynecol Oncol 2011;121:54-8.

23. Karageorgi S, Prescott J, Wong JY, et al. GSTM1 and GSTT1 copy number variation in population-based studies of endometrial cancer risk. Cancer Epidemiol Biomarkers Prev 2011;20:1447-52.

24. Konopka B, Janiec-Jankowska A, Kwiatkowska E, et al. PIK3CA mutations and amplification in endometrioid endometrial carcinomas: relation to other genetic defects and clinicopathologic status of the tumors. Hum Pathol 2011;42:1710-9.

25. Krupa R, Sobczuk A, Poplawski T, et al. DNA damage and repair in endometrial cancer in correlation with the hOGG1 and RAD51 genes polymorphism. Mol Biol Rep 2011;38:1163-70.

26. Lacey JV Jr, Yang H, Gaudet MM, et al. Endometrial cancer and genetic variation in PTEN, PIK3CA, AKT1, MLH1, and MSH2 within a population-based case-control study. Gynecol Oncol 2011;120:167-73.

27. Li G, Xiang YB, Courtney R, et al. Association of a single nucleotide polymorphism at 6q25.1,rs2046210, with endometrial cancer risk among Chinese women. Chin J Cancer 2011;30:138-43.

28. Lurie G, Gaudet MM, Spurdle AB, et al. The obesityassociated polymorphisms FTO rs9939609 and MC4R rs17782313 and endometrial cancer risk in non-Hispanic white women. PloS One 2011;6:e16756.

29. Walker JC, Goodfellow PJ. Traditional Approaches to Molecular Genetic Analysis. In: Ellenson LH. Molecular Genetics of Endometrial Carcinoma (Advances in
Experimental Medicine and Biology). 1st edition. New York: Springer, 2017:99-118.

30. Yeramian A, Moreno-Bueno G, Dolcet X, et al. Endometrial carcinoma: molecular alterations involved in tumor development and progression. Oncogene 2013;32:403-13.

31. Matias-Guiu X, Prat J. Molecular pathology of endometrial carcinoma. Histopathology 2013;62:111-23.

32. Bohaumilitzky L, von Knebel Doeberitz M, Kloor M, et al. Implications of Hereditary Origin on the Immune Phenotype of Mismatch Repair-Deficient Cancers: Systematic Literature Review. J Clin Med 2020;9:E1741.

33. Kloor M, von Knebel Doeberitz M. The Immune Biology of Microsatellite-Unstable Cancer. Trends Cancer 2016;2:121-33.

34. Wild PJ, Ikenberg K, Fuchs TJ, et al. p53 suppresses type II endometrial carcinomas in mice and governs endometrial tumour aggressiveness in humans. EMBO Mol Med 2012;4:808-24.

35. Winder AD, Maniar KP, Wei JJ, et al. Synuclein-gamma in uterine serous carcinoma impacts survival: an NRG Oncology/Gynecologic Oncology Group study. Cancer 2017;123:1144-55.

36. Bafligil C, Thompson DJ, Lophatananon A, et al. Association between genetic polymorphisms and endometrial cancer risk: a systematic review. J Med Genet 2020;57:591-600.

37. Benati M, Montagnana M, Danese E, et al. Aberrant Telomere Length in Circulating Cell-Free DNA as Possible Blood Biomarker with High Diagnostic Performance in Endometrial Cancer. Pathol Oncol Res 2020;26:2281-9.

38. Talhouk A, McConechy MK, Leung S, et al. A clinically applicable molecular-based classification for endometrial cancers, Br J Cancer 2015;113:299-310.

39. Stelloo E, Bosse T, Nout RA, et al. Refining prognosis and identifying targetable pathways for high-risk endometrial cancer; a TransPORTEC initiative. Mod Pathol 2015;28:836-44.

40. Stelloo E, Nout RA, Osse EM, et al. Improved Risk Assessment by Integrating Molecular and Clinicopathological Factors in Early-stage Endometrial Cancer-Combined Analysis of the PORTEC Cohorts. Clin Cancer Res 2016;22:4215-24.

41. Casarin J, Bogani G, Serati M, et al. Presence of Glandular Cells at the Preoperative Cervical Cytology and Local Recurrence in Endometrial Cancer. Int J Gynecol Pathol 2020;39:522-8. 
42. Guida M, Ligresti A, De Filippis D, et al. The levels of the endocannabinoid receptor CB2 and its ligand 2-arachidonoylglycerol are elevated in endometrial carcinoma. Endocrinology 2010;151:921-8.

43. Grauso F, De Franciscis P, Schiattarella A, et al. A review on the role of the endocannabinoid system in the gynecological malignancy. Ital J Gynaecol Obstet 2019;31:35-41.

44. Hinchcliff EM, Bednar EM, Lu KH, et al. Disparities in gynecologic cancer genetics evaluation. Gynecol Oncol 2019;153:184-91.

45. Laganà AS, La Rosa VL, Rapisarda AM, et al. Comment on: "Needs and priorities of women with endometrial and cervical cancer". J Psychosom Obstet Gynaecol 2017;38:85-6.

46. Vitale SG, Rossetti D, Tropea A, et al. Fertility sparing surgery for stage IA type I and G2 endometrial cancer in reproductive-aged patients: evidence-based approach and future perspectives. Updates Surg 2017;69:29-34.

47. Vitale SG, Capriglione S, Zito G, et al. Management of endometrial, ovarian and cervical cancer in the elderly: current approach to a challenging condition. Arch Gynecol Obstet 2019;299:299-315.

48. Lolkema MP, Gadellaa-van Hooijdonk CG, Bredenoord

Cite this article as: Bianco B, Barbosa CP, Trevisan CM, Laganà AS, Montagna E. Endometrial cancer: a genetic point of view. Transl Cancer Res 2020;9(12):7706-7715. doi: 10.21037/tcr20-2334
AL, et al. Ethical, legal, and counseling challenges surrounding the return of genetic results in oncology. J Clin Oncol 2013;31:1842-8.

49. Heald B, Rybicki L, Clements D, et al. Assessment of clinical workload for general and specialty genetic counsellors at an academic medical center: a tool for evaluating genetic counselling practices. NPJ Genom Med 2016;1:16010.

50. Kim JY, Byeon JS. Genetic Counseling and Surveillance Focused on Lynch Syndrome. J Anus Rectum Colon 2019;3:60-8.

51. Ferlay J, Soerjomataram I, Dikshit R, et al. Cancer incidence and mortality worldwide: sources, methods and major patterns in GLOBOCAN 2012. Int J Cancer 2015;136:E359-86.

52. Oktay K, Harvey BE, Partridge AH, et al. Fertility Preservation in Patients with Cancer: ASCO Clinical Practice Guideline Update. J Clin Oncol 2018;36:1994-2001.

53. La Rosa VL, Garzon S, Gullo G, et al. Fertility preservation in women affected by gynaecological cancer: the importance of an integrated gynaecological and psychological approach. Ecancermedicalscience 2020;14:1035. 


\section{References}

1. Ashton KA, Proietto A, Otton G, et al. Toll-like receptor (TLR) and nucleosome-binding oligomerization domain (NOD) gene polymorphisms and endometrial cancer risk. BMC cancer 2010;10:382.

2. Stelloo E, Nout RA, Osse EM, et al. Improved Risk Assessment by Integrating Molecular and Clinicopathological Factors in Early-stage Endometrial Cancer-Combined Analysis of the PORTEC Cohorts. Clin Cancer Res 2016;22:4215-24.

3. Alves M, Carreira I, Liberato $P$, et al. Identification of a 0.4 $\mathrm{Kb}$ deletion region in 10q26 associated with endometrial carcinoma. Oncol Rep 2010;23:519-22.

4. Ashton KA, Proietto A, Otton G, et al. Polymorphisms in genes of the steroid hormone biosynthesis and metabolism pathways and endometrial cancer risk. Cancer Epidemiol 2010;34:328-37.

5. Ashton KA, Proietto A, Otton G, et al. Toll-like receptor (TLR) and nucleosome-binding oligomerization domain (NOD) gene polymorphisms and endometrial cancer risk. BMC cancer 2010;10:382.

6. Bilbao C, Lara PC, Ramirez R, et al. Microsatellite instability predicts clinical outcome in radiation-treated endometrioid endometrial cancer. Int J Radiat Oncol Biol Phys 2010;76:9-13.

7. Cayan F, Tok E, Aras-Ates N, et al. Insulin receptor substrate-2 gene polymorphism: is it associated with endometrial cancer? Gynecol Endocrinol 2010;26:378-82.

8. Dobrzycka B, Terlikowski SJ, Mazurek A, et al. Circulating free DNA, p53 antibody and mutations of KRAS gene in endometrial cancer. Int J Cancer 2010;127:612-21.

9. Gaudet MM, Yang HP, Bosquet JG, et al. No association between FTO or HHEX and endometrial cancer risk. Cancer Epidemiol Biomarkers Prev 2010;19:2106-9.

10. Ghasemi N, Karimi-Zarchi M, Mortazavi-Zadeh MR, et al. Evaluation of the frequency of TP53 gene codon 72 polymorphisms in Iranian patients with endometrial cancer. Cancer Genet Cytogenet 2010;196:167-70.

11. Janiec-Jankowska A, Konopka B, Goluda C, et al. TP53 mutations in endometrial cancers: relation to PTEN gene defects. Int J Gynecol Cancer 2010;20:196-202.

12. Lee E, Hsu C, Haiman CA, et al. Genetic variation in the progesterone receptor gene and risk of endometrial cancer: a haplotype-based approach. Carcinogenesis 2010;31:1392-9.

13. Low YL, Li Y, Humphreys K, et al. Multi-variant pathway association analysis reveals the importance of genetic determinants of estrogen metabolism in breast and endometrial cancer susceptibility. PLoS Genet 2010;6:e1001012.

14. Murayama-Hosokawa S, Oda K, Nakagawa S, et al. Genome-wide single-nucleotide polymorphism arrays in endometrial carcinomas associate extensive chromosomal instability with poor prognosis and unveil frequent chromosomal imbalances involved in the PI3-kinase pathway. Oncogene 2010;29:1897-908.

15. Prescott J, McGrath M, Lee IM, et al. Telomere length and genetic analyses in population-based studies of endometrial cancer risk. Cancer 2010;116:4275-82.

16. Sliwinski T, Sitarek P, Stetkiewicz T, et al. Polymorphism of the ERalpha and CYP1B1 genes in endometrial cancer in a Polish subpopulation. J Obstet Gynaecol Res 2010;36:311-7.

17. Terry K, McGrath M, Lee IM, et al. Genetic variation in CYP11A1 and StAR in relation to endometrial cancer risk. Gynecol Oncol 2010;117:255-9.

18. Wang PH, Yi YC, Tsai HT, et al. Significant association of genetic polymorphism of human nonmetastatic clone 23 type 1 gene with an increased risk of endometrial cancer. Gynecol Oncol 2010;119:70-5.

19. Yang HP, Gonzalez Bosquet J, Li Q, et al. Common genetic variation in the sex hormone metabolic pathway and endometrial cancer risk: pathway-based evaluation of candidate genes. Carcinogenesis 2010;31:827-33.

20. Yi YC, Chou PT, Chen LY, et al. Matrix metalloproteinase-7 (MMP-7) polymorphism is a risk factor for endometrial cancer susceptibility. Clin Chem Lab Med 2010;48:337-44.

21. Cheung LW, Hennessy BT, Li J, et al. High frequency of PIK3R1 and PIK3R2 mutations in endometrial cancer elucidates a novel mechanism for regulation of PTEN protein stability. Cancer Discov 2011;1:170-85.

22. Doherty JA, Weiss NS, Fish S, et al. Polymorphisms in nucleotide excision repair genes and endometrial cancer risk. Cancer Epidemiol Biomarkers Prev 2011;20:1873-82.

23. Hlavna M, Kohut L, Lipkova J, et al. Relationship of resistin levels with endometrial cancer risk. Neoplasma 2011;58:124-8.

24. Karageorgi S, McGrath M, Lee IM, et al. Polymorphisms in genes hydroxysteroid-dehydrogenase-17b type 2 and type 4 and endometrial cancer risk. Gynecol Oncol 2011;121:54-8.

25. Karageorgi S, Prescott J, Wong JY, et al. GSTM1 and GSTT1 copy number variation in population-based studies of endometrial cancer risk. Cancer Epidemiol 
Biomarkers Prev 2011;20:1447-52.

26. Konopka B, Janiec-Jankowska A, Kwiatkowska E, et al. PIK3CA mutations and amplification in endometrioid endometrial carcinomas: relation to other genetic defects and clinicopathologic status of the tumors. Hum Pathol 2011;42:1710-9.

27. Krupa R, Sobczuk A, Poplawski T, et al. DNA damage and repair in endometrial cancer in correlation with the hOGG1 and RAD51 genes polymorphism. Mol Biol Rep 2011;38:1163-70.

28. Lacey JV Jr, Yang H, Gaudet MM, et al. Endometrial cancer and genetic variation in PTEN, PIK3CA, AKT1, MLH1, and MSH2 within a population-based case-control study. Gynecol Oncol 2011;120:167-73.

29. Li G, Xiang YB, Courtney R, et al. Association of a single nucleotide polymorphism at 6q25.1,rs2046210, with endometrial cancer risk among Chinese women. Chin J Cancer 2011;30:138-43.

30. Lurie G, Gaudet MM, Spurdle AB, et al. The obesityassociated polymorphisms FTO rs9939609 and MC4R rs17782313 and endometrial cancer risk in non-Hispanic white women. PloS One 2011;6:e16756.

31. McGrath M, Lee IM, Buring J, et al. Common genetic variation within IGFI, IGFII, IGFBP-1, and IGFBP-3 and endometrial cancer risk. Gynecol Oncol 2011;120:174-8.

32. O'Mara TA, Fahey P, Ferguson K, et al. Progesterone receptor gene variants and risk of endometrial cancer. Carcinogenesis 2011;32:331-5.

33. O'Mara TA, Ferguson K, Fahey P, et al. CHEK2, MGMT, SULT1E1 and SULT1A1 polymorphisms and endometrial cancer risk. Twin Res Hum Genet 2011;14:328-32.

34. Spurdle AB, Thompson DJ, Ahmed S, et al. Genome-wide association study identifies a common variant associated with risk of endometrial cancer. Nat Genet 2011;43:451-4.

35. Steinbakk A, Malpica A, Slewa A, et al. High frequency microsatellite instability has a prognostic value in endometrial endometrioid adenocarcinoma, but only in FIGO stage 1 cases. Cell Oncol (Dordr) 2011;34:457-65.

36. Su CK, Yeh KT, Yeh CB, et al. Genetic polymorphism of the plasminogen activator inhibitor- 1 is associated with an increased risk of endometrial cancer. J Surg Oncol 2011;104:755-9.

37. Wong TF, Yoshinaga K, Monma Y, et al. Association of keap1 and nrf2 genetic mutations and polymorphisms with endometrioid endometrial adenocarcinoma survival. Int J Gynecol Cancer 2011;21:1428-35.

38. Zighelboim I, Reinhart AJ, Gao F, et al. DICER1 expression and outcomes in endometrioid endometrial adenocarcinoma. Cancer 2011;117:1446-53.

39. Cacina C, Bulgurcuoglu-Kuran S, Iyibozkurt AC, et al. Genetic variants of SDF-1 and CXCR4 genes in endometrial carcinoma. Mol Biol Rep 2012;39:1225-9.

40. Chen X, Xiang YB, Long JR, et al. Genetic polymorphisms in obesity-related genes and endometrial cancer risk. Cancer 2012;118:3356-64.

41. Correa-Noronha SA, Noronha SM, Alecrim C, et al. Association of angiotensin-converting enzyme I gene I/ D polymorphism with endometrial but not with ovarian cancer. Gynecol Endocrinol 2012;28:889-91.

42. Cossu-Rocca P, Contini M, Uras MG, et al. Tyrosine kinase receptor status in endometrial stromal sarcoma: an immunohistochemical and genetic-molecular analysis. Int J Gynecol Pathol 2012;31:570-9.

43. Cote ML, Kam A, Chang CY, et al. A pilot study of microsatellite instability and endometrial cancer survival in white and African American women. Int J Gynecol Pathol 2012;31:66-72.

44. Gilabert-Estellés J, Ramon LA, Braza-Boils A, et al. Plasminogen activator inhibitor-1 (PAI-1) 4 G/5 G polymorphism and endometrial cancer. Influence of PAI-1 polymorphism on tissue PAI-1 antigen and mRNA expression and tumor severity. Thromb Res 2012;130:242-7.

45. Ikeda Y, Oda K, Nakagawa S, et al. Genome-wide single nucleotide polymorphism arrays as a diagnostic tool in patients with synchronous endometrial and ovarian cancer. Int J Gynecol Cancer 2012;22:725-31.

46. Knappskog S, Trovik J, Marcickiewicz J, et al. SNP285C modulates oestrogen receptor/Sp1 binding to the MDM2 promoter and reduces the risk of endometrial but not prostatic cancer. Eur J Cancer 2012;48:1988-96.

47. Kowalewska M, Danska-Bidzinska A, Bakula-Zalewska $\mathrm{E}$, et al. Identification of suitable reference genes for gene expression measurement in uterine sarcoma and carcinosarcoma tumors. Clin Biochem 2012;45:368-71.

48. Leslie KK, Sill MW, Lankes HA, et al. Lapatinib and potential prognostic value of EGFR mutations in a Gynecologic Oncology Group phase II trial of persistent or recurrent endometrial cancer. Gynecol Oncol 2012;127:345-50.

49. Li Y, Low HQ, Foo JN, et al. Genetic variants in ER cofactor genes and endometrial cancer risk. PloS One 2012;7:e42445.

50. Long J, Zheng W, Xiang YB, et al. Genome-wide association study identifies a possible susceptibility locus for endometrial cancer. Cancer Epidemiol Biomarkers Prev 2012;21:980-7. 
51. Lundin E, Wirgin I, Lukanova A, et al. Selected polymorphisms in sex hormone-related genes, circulating sex hormones and risk of endometrial cancer. Cancer Epidemiol 2012;36:445-52.

52. Nevadunsky NS, Korneeva I, Caputo T, et al. Mannosebinding lectin codon 54 genetic polymorphism and vaginal protein levels in women with gynecologic malignancies. Eur J Obstet Gynecol Reprod Biol 2012;163:216-8.

53. Nikolic A, Ristanovic M, Perovic V, et al. Genetic alterations in SMAD4 and K-ras in Serbian patients with endometrial carcinoma. Int J Gynecol Cancer 2012;22:442-6.

54. Razavi P, Lee E, Bernstein L, et al. Variations in sex hormone metabolism genes, postmenopausal hormone therapy and risk of endometrial cancer. Int J Cancer 2012;130:1629-38.

55. Romanowicz-Makowska H, Smolarz B, Polac I, et al. Single nucleotide polymorphisms of RAD51 G135C, XRCC2 Arg188His and XRCC3 Thr241Met homologous recombination repair genes and the risk of sporadic endometrial cancer in Polish women. J Obstet Gynaecol Res 2012;38:918-24.

56. Setiawan VW, Haessler J, Schumacher F, et al. HNF1B and endometrial cancer risk: results from the PAGE study. PloS One 2012;7:e30390.

57. Sobczuk A, Poplawski T, Blasiak J. Polymorphisms of DNA repair genes in endometrial cancer. Pathol Oncol Res 2012;18:1015-20.

58. Tong SY, Lee JM, Ki KD, et al. Genetic polymorphism of PRKCDBP is associated with an increased risk of endometrial cancer. Cancer Invest 2012;30:642-5.

59. Wang LE, Ma H, Hale KS, et al. Roles of genetic variants in the PI3K and RAS/RAF pathways in susceptibility to endometrial cancer and clinical outcomes. J Cancer Res Clin Oncol 2012;138:377-85.

60. Zahedi P, Aminimoghaddam S, Sayahpour FA, et al. Association of survivin gene polymorphism with endometrial cancer. Int J Gynecol Cancer 2012;22:35-7.

61. Zheng YY, Xie L, Liu L, et al. BAT-25 polymorphism in Chinese from Jiangsu province and its implication for locus microsatellite instability screening. Int J Biol Markers 2012;27:e227-31.

62. Zaj c A, Stachowiak G, Pertynski T, et al. Association between MDM2 SNP309 polymorphism and endometrial cancer risk in Polish women. Pol J Pathol 2012;63:278-83.

63. Davis SJ, Sheppard KE, Pearson RB, et al. Functional analysis of genes in regions commonly amplified in highgrade serous and endometrioid ovarian cancer. Clin Cancer Res 2013;19:1411-21.
64. Delahanty RJ, Xiang YB, Spurdle A, et al. Polymorphisms in inflammation pathway genes and endometrial cancer risk. Cancer Epidemiol Biomarkers Prev 2013;22:216-23.

65. Dorjgochoo T, Xiang YB, Long J, et al. Association of genetic markers in the BCL-2 family of apoptosisrelated genes with endometrial cancer risk in a Chinese population. PloS One 2013;8:e60915.

66. Hirasawa A, Zama T, Akahane T, et al. Polymorphisms in the UGT1A1 gene predict adverse effects of irinotecan in the treatment of gynecologic cancer in Japanese patients. J Hum Genet 2013;58:794-8.

67. Hosono S, Matsuo K, Ito H, et al. Polymorphisms in base excision repair genes are associated with endometrial cancer risk among postmenopausal Japanese women. Int J Gynecol Cancer 2013;23:1561-8.

68. Hsu YT, Gu F, Huang YW, et al. Promoter hypomethylation of EpCAM-regulated bone morphogenetic protein gene family in recurrent endometrial cancer. Clin Cancer Res 2013;19:6272-85.

69. Jarzabek K, Koda M, Walentowicz-Sadlecka M, et al. Altered expression of ERs, aromatase, and COX2 connected to estrogen action in type 1 endometrial cancer biology. Tumour Biol 2013;34:4007-16.

70. Li D, Takao T, Tsunematsu R, et al. Inhibition of AHR transcription by NF1C is affected by a single-nucleotide polymorphism, and is involved in suppression of human uterine endometrial cancer. Oncogene 2013;32:4950-9.

71. Liu JJ, Bertrand KA, Karageorgi S, et al. Prospective analysis of vitamin $\mathrm{D}$ and endometrial cancer risk. Ann Oncol 2013;24:687-92.

72. Liu JJ, Hazra A, Giovannucci E, et al. One-carbon metabolism factors and endometrial cancer risk. $\mathrm{Br} \mathrm{J}$ Cancer 2013;108:183-7.

73. Meng F, Li H, Zhou R, et al. LAPTM4B gene polymorphism and endometrial carcinoma risk and prognosis. Biomarkers 2013;18:136-43.

74. Palles C, Cazier JB, Howarth KM, et al. Germline mutations affecting the proofreading domains of POLE and POLD1 predispose to colorectal adenomas and carcinomas. Nat Genet 2013;45:136-44. Erratum in: Nat Genet 2013;45:713.

75. Wik E, Birkeland E, Trovik J, et al. High phosphoStathmin(Serine38) expression identifies aggressive endometrial cancer and suggests an association with PI3K inhibition. Clin Cancer Res 2013;19:2331-41.

76. Wik E, Raeder MB, Krakstad C, et al. Lack of estrogen receptor-alpha is associated with epithelial-mesenchymal transition and PI3K alterations in endometrial carcinoma. 
Clin Cancer Res 2013;19:1094-105.

77. Yoneda T, Kuboyama A, Kato K, et al. Association of MDM2 SNP309 and TP53 Arg72Pro polymorphisms with risk of endometrial cancer. Oncol Rep 2013;30:25-34.

78. Zaj c A, Stachowiak G, Smolarz B, et al. Polymorphisms of codon 72 of the TP53 gene in endometrial carcinoma of postmenopausal women. Postepy Hig Med Dosw (Online) 2013;67:1312-8.

79. Zhao S, Choi M, Overton JD, et al. Landscape of somatic single-nucleotide and copy-number mutations in uterine serous carcinoma. PNAS 2013;110:2916-21.

80. De Vivo I, Prescott J, Setiawan VW, et al. Genome-wide association study of endometrial cancer in E2C2. Hum Genet 2014;133:211-24.

81. Forma E, Wójcik-Krowiranda K, Jó wiak P, et al. Topoisomerase II binding protein 1 c.*229C $>\mathrm{T}$ (rs115160714) gene polymorphism and endometrial cancer risk. Pathol Oncol Res 2014;20:597-602.

82. Gatalica Z, Snyder C, Maney T, et al. Programmed cell death 1 (PD-1) and its ligand (PD-L1) in common cancers and their correlation with molecular cancer type. Cancer Epidemiol Biomarkers Prev 2014;23:2965-70.

83. Kafshdooz L, Tabrizi AD, Mohaddes SM, et al. The polymorphism of hypoxia-inducible factor-1a gene in endometrial cancer. Asian Pac J Cancer Prev 2014;15:10393-6.

84. Kafshdooz T, Tabrizi AD, Mohaddes Ardabili SM, et al. Polymorphism of p53 gene codon 72 in endometrial cancer: correlation with tumor grade and histological type. Asian Pac J Cancer Prev 2014;15:9603-6.

85. Knappskog S, Gansmo LB, Dibirova K, et al. Population distribution and ancestry of the cancer protective MDM2 SNP285 (rs117039649). Oncotarget 2014;5:8223-34.

86. Lattrich C, Haring J, Schuler S, et al. Polymorphisms in the promoter region of estrogen receptor beta gene in endometrial cancer. Arch Gynecol Obstet 2014;289:631-5.

87. Lee LJ, Ratner E, Uduman M, et al. The KRAS-variant and miRNA expression in RTOG endometrial cancer clinical trials 9708 and 9905. PloS One 2014;9:e94167.

88. Maiques O, Cuevas D, Garcia Dios DA, et al. FISH analysis of PTEN in endometrial carcinoma. Comparison with SNP arrays and MLPA. Histopathology 2014;65:371-88.

89. Michalska MM, Samulak D, Romanowicz H, et al. Association of polymorphisms in the 5' untranslated region of RAD51 gene with risk of endometrial cancer in the Polish population. Arch Gynecol Obstet 2014;290:985-91.

90. Qiu CP, Lv QT, Dongol S, et al. Single nucleotide polymorphism of SREBF-1 gene associated with an increased risk of endometrial cancer in Chinese women. PloS One 2014;9:e90491.

91. Rudd ML, Mohamed H, Price JC, et al. Mutational analysis of the tyrosine kinome in serous and clear cell endometrial cancer uncovers rare somatic mutations in TNK2 and DDR1. BMC Cancer 2014;14:884.

92. Stelloo E, Nout RA, Naves LC, et al. High concordance of molecular tumor alterations between pre-operative curettage and hysterectomy specimens in patients with endometrial carcinoma. Gynecol Oncol 2014;133:197-204.

93. Williams KA, Terry KL, Tworoger SS, et al. Polymorphisms of MUC16 (CA125) and MUC1 (CA15.3) in relation to ovarian cancer risk and survival. PloS One 2014;9:e88334.

94. Zaj c A, Smolarz B, Stachowiak G, et al. TP53 and MDM2 polymorphisms and the risk of endometrial cancer in postmenopausal women. Med Oncol 2014;31:286.

95. Zhang B, Xing X, Li J, et al. Comparative DNA methylome analysis of endometrial carcinoma reveals complex and distinct deregulation of cancer promoters and enhancers. BMC Genomics 2014;15:868.

96. Aminimoghaddam S, Shahrabi-Farahani M, MohajeriTehrani M, et al. Epistatic interaction between adiponectin and survivin gene polymorphisms in endometrial carcinoma. Pathol Res Pract 2015;211:293-7.

97. Bae HS, Kim H, Young Kwon S, et al. Should endometrial clear cell carcinoma be classified as Type II endometrial carcinoma? Int J Gynecol Pathol 2015;34:74-84.

98. Berg A, Hoivik EA, Mjos S, et al. Molecular profiling of endometrial carcinoma precursor, primary and metastatic lesions suggests different targets for treatment in obese compared to non-obese patients. Oncotarget 2015;6:1327-39.

99. Carvajal-Carmona LG, O'Mara TA, Painter JN, et al. Candidate locus analysis of the TERT-CLPTM1L cancer risk region on chromosome 5p15 identifies multiple independent variants associated with endometrial cancer risk. Hum Genet 2015;134:231-45.

100.Fallah S, Korani M, Hajimirza M, et al. Association Between Genetic Variants of Akt1 and Endometrial Cancer. Biochem Genet 2015;53:281-90.

101.Ivanova TI, Krikunova LI, Ryabchenko NI, et al. Association of the apolipoprotein E 2 allele with concurrent occurrence of endometrial hyperplasia and endometrial carcinoma. Oxid Med Cell Longev 2015;2015:593658.

102. Kafshdooz L, Kafshdooz T, Tabrizi AD, et al. Role of exon 7 PTEN Gene in Endometrial Carcinoma. Asian Pac J Cancer Prev 2015;16:4521-4. 
103. Kafshdooz T, Mohaddes Ardabili SM, Kafshdooz L, et al. C-kit Mutations in Endometrial Cancer: Correlation with Tumor Histologic Type. Asian Pac J Cancer Prev 2015;16:7449-52.

104. Kito M, Motoyama S, Fujita K, et al. CRP 1846C>T Genetic Polymorphism Is Associated with Lymph Node Metastasis and/or Severe Lymphatic Invasion in Endometrial Cancer. Tohoku J Exp Med 2015;237:25-30.

105. Mandato VD, Farnetti E, Torricelli F, et al. HNF1B polymorphism influences the prognosis of endometrial cancer patients: a cohort study. BMC Cancer 2015;15:229.

106. Michalska MM, Samulak D, Bienkiewicz J, et al. Association between $-41657 \mathrm{C} / \mathrm{T}$ single nucleotide polymorphism of DNA repair gene XRCC2 and endometrial cancer risk in Polish women. Pol J Pathol 2015;66:67-71.

107. Moir-Meyer GL, Pearson JF, Lose F, et al. Rare germline copy number deletions of likely functional importance are implicated in endometrial cancer predisposition. Hum Genet 2015;134:269-78.

108. Nallapalle SR, Daripally S, Prasad VT. Promoter polymorphism of FASL confers protection against femalespecific cancers and those of FAS impact the cancers divergently. Tumour Biol 2015;36:2709-24.

109. O'Mara TA, Glubb DM, Painter JN, et al. Comprehensive genetic assessment of the ESR1 locus identifies a risk region for endometrial cancer. Endocr Relat Cancer 2015;22:851-61.

110. Okamoto K, Tsunematsu R, Tahira T, et al. SNP55, a new functional polymorphism of MDM2-P2 promoter, contributes to allele-specific expression of MDM2 in endometrial cancers. BMC Med Genet 2015;16:67.

111. Painter JN, O'Mara TA, Batra J, et al. Fine-mapping of the HNF1B multicancer locus identifies candidate variants that mediate endometrial cancer risk. Hum Mol Genet 2015;24:1478-92.

112.Płuciennik E, Nowakowska M, Pospiech K, et al. The role of WWOX tumor suppressor gene in the regulation of EMT process via regulation of CDH1-ZEB1VIM expression in endometrial cancer. Int J Oncol 2015;46:2639-48.

113.Stefansson IM, Raeder M, Wik E, et al. Increased angiogenesis is associated with a 32-gene expression signature and 6p21 amplification in aggressive endometrial cancer. Oncotarget 2015;6:10634-45.

114. Suga Y, Sugai T, Uesugi N, et al. Molecular analysis of isolated tumor glands from endometrial endometrioid adenocarcinomas. Pathol Int 2015;65:240-9.
115.Sutton J, Orloff MS, Michener C, et al. Association of specific PTEN/10q haplotypes with endometrial cancer phenotypes in African-American and European American women. Gynecol Oncol 2015;138:434-40.

116. Tamura R, Yoshihara K, Yamawaki K, et al. Novel kinase fusion transcripts found in endometrial cancer. Sci Rep 2015;5:18657.

117. Torricelli F, Mandato VD, Farnetti E, et al. Polymorphisms in cyclooxygenase-2 gene in endometrial cancer patients. Tumour Biol 2015;36:7423-30.

118. Walker CJ, Miranda MA, O'Hern MJ, et al. Patterns of CTCF and ZFHX3 Mutation and Associated Outcomes in Endometrial Cancer. J Natl Cancer Inst 2015;107:djv249.

119. Wang L, Fang L, Cui Y. Association between ERBB4 gene polymorphism in the microRNA binding site and endometrial carcinoma risk. Genes Genom 2015;37:1035-9.

120. Wang L, Li J, Lu H, et al. Association analysis between 8-oxoguanine DNA glycosylase genetic variants and endometrial cancer susceptibility in Chinese Han population. J Pharm Pharmacol 2015;67:559-64.

121. Wang L, Lu H, Li J, et al. The association between XRCC1 genetic polymorphisms and the risk of endometrial carcinoma in Chinese. Gene 2015;554:155-9.

122. Wong SQ, Fellowes A, Doig K, et al. Assessing the clinical value of targeted massively parallel sequencing in a longitudinal, prospective population-based study of cancer patients. Br J Cancer 2015;112:1411-20.

123. Yin D, Jiang Y, Zhang S, et al. No association between p21 gene rs1059234 polymorphisms and risk of endometrial cancer among Han women in Northeast China. Cell Biochem Biophys 2015;71:167-71.

124. Yu X, Zhou B, Zhang Z, et al. Significant association between IL-32 gene polymorphisms and susceptibility to endometrial cancer in Chinese Han women. Tumour Biol 2015;36:5265-72.

125.Zheng LY, Song AP, Chen L, et al. Association of genetic polymorphisms in AURKA, BRCA1, CCNE1 and CDK2 with the risk of endometrial carcinoma and clinicopathological parameters among Chinese Han women. Eur J Obstet Gynecol Reprod Biol 2015;184:65-72.

126. Anglesio MS, Wang YK, Maassen M, et al. Synchronous Endometrial and Ovarian Carcinomas: Evidence of Clonality. J Natl Cancer Inst 2016;108:djv428.

127. Bieńkiewicz J, Smolarz B, Malinowski A. Association Between Single Nucleotide Polymorphism +276G > T (rs1501299) in ADIPOQ and Endometrial Cancer. Pathol Oncol Res 2016;22:135-8.

128. Bolton KA, Holliday EG, Attia J, et al. A novel 
polymorphic repeat in the upstream regulatory region of the estrogen-induced gene EIG121 is not associated with the risk of developing breast or endometrial cancer. BMC Res Notes 2016;9:287.

129. Chao A, Wu RC, Jung SM, et al. Implication of genomic characterization in synchronous endometrial and ovarian cancers of endometrioid histology. Gynecol Oncol 2016;143:60-7.

130. Chen L, Liu MM, Liu H, et al. ERCC1 and XRCC1 but not XPA single nucleotide polymorphisms correlate with response to chemotherapy in endometrial carcinoma. Onco Targets Ther 2016;9:7019-28.

131. Hogervorst JG, van den Brandt PA, Godschalk RW, et al. The influence of single nucleotide polymorphisms on the association between dietary acrylamide intake and endometrial cancer risk. Sci Rep 2016;6:34902.

132. Kaveh F, Baumbusch LO, Nebdal D, et al. A systematic comparison of copy number alterations in four types of female cancer. BMC Cancer 2016;16:913.

133. Kwasniewski W, Gozdzicka-Jozefiak A, Wolun-Cholewa $\mathrm{M}$, et al. Microsatellite polymorphism in the $\mathrm{P} 1$ promoter region of the IGF1 gene is associated with endometrial cancer. Mol Med Rep 2016;13:4950-8.

134. Menghi F, Inaki K, Woo X, et al. The tandem duplicator phenotype as a distinct genomic configuration in cancer. PNAS 2016;113:E2373-82.

135.Michalska MM, Samulak D, Jablonski F, et al. The R156R ERCC2 polymorphism as a risk factor of endometrial cancer. Tumour Biol 2016;37:2171-6.

136. Nagasawa T, Sugai T, Shoji T, et al. Molecular Analysis of Single Tumor Glands Using the Crypt Isolation Method in Endometrial Carcinomas. Int J Gynecol Cancer 2016;26:1658-66.

137.Pringle KG, Delforce SJ, Wang Y, et al. Renin-angiotensin system gene polymorphisms and endometrial cancer. Endocr Connect 2016;5:128-35.

138. Ramirez-Garcia SA, Flores-Alvarado LJ, Topete-Gonzalez LR, et al. High frequency of ancestral allele of the TJP1 polymorphism rs2291166 in Mexican population, conformational effect and applications in surgery and medicine. Cir Cir 2016;84:28-36.

139. Sun D, Fan YJ, Chen YM, et al. BRCA1 single nucleotide polymorphisms and microsatellite instability in endometrial cancer and their association with patient prognosis in a Chinese population. Eur J Gynaecol Oncol 2016;38:871-7.

140.Sun Y, Zhang L, Ho SS, et al. Lower mitochondrial DNA copy number in peripheral blood leukocytes increases the risk of endometrial cancer. Mol Carcinog 2016;55:1111-7.
141. Thompson DJ, O'Mara TA, Glubb DM, et al. CYP19A1 fine-mapping and Mendelian randomization: estradiol is causal for endometrial cancer. Endocr Relat Cancer 2016;23:77-91.

142. Wang HY, Zhang JJ, Zheng XY, et al. Association between IL-6 Gene (-174 \& -572 G/C) Polymorphisms and Endometrial Adenocarcinoma Risk. Pathol Oncol Res 2016;22:825-9.

143. Yang L, Wang YJ, Zheng LY, et al. Genetic Polymorphisms of TGFB1, TGFBR1, SNAI1 and TWIST1 Are Associated with Endometrial Cancer Susceptibility in Chinese Han Women. PloS One 2016;11:e0155270.

144. Yu X, Zhou B, Zhang Z, et al. Insertion/deletion polymorphism in IL1A 3'-UTR is associated with susceptibility to endometrial cancer in Chinese Han women. J Obstet Gynaecol Res 2016;42:983-9.

145.Zhao X, Wei X, Zhao L, et al. The rs6983267 SNP and long non-coding RNA CARLo-5 are associated with endometrial carcinoma. Environ Mol Mutagen 2016;57:508-15.

146.Ayhan A, Kuhn E, Wu RC, et al. CCNE1 copynumber gain and overexpression identify ovarian clear cell carcinoma with a poor prognosis. Mod Pathol 2017;30:297-303.

147. Bie kiewicz J, Romanowicz H, Malinowski A, et al. Association of Single Nucleotide Polymorphism -2548 G/ A (rs12112075) of leptin gene with endometrial cancer and uterine leiomyomas. Eur J Obstet Gynecol Reprod Biol 2017;218:113-8.

148. Chang YS, Huang HD, Yeh KT, et al. Identification of novel mutations in endometrial cancer patients by wholeexome sequencing. Int J Oncol 2017;50:1778-84.

149.Depreeuw J, Stelloo E, Osse EM, et al. Amplification of 1q32.1 Refines the Molecular Classification of Endometrial Carcinoma. Clin Cancer Res 2017;23:7232-41.

150. Fialkova V, Vidomanova E, Balharek T, et al. DNA methylation as mechanism of apoptotic resistance development in endometrial cancer patients. Gen Physiol Biophys 2017;36:521-9.

151. Gansmo LB, Bjornslett M, Halle MK, et al. MDM2 promoter polymorphism del1518 (rs3730485) and its impact on endometrial and ovarian cancer risk. BMC Cancer 2017;17:97.

152.Hu JL, Hu XL, Han Q, et al. INSR gene polymorphisms correlate with sensitivity to platinum-based chemotherapy and prognosis in patients with epithelial ovarian cancer. Gene Ther 2017;24:392-8.

153.Pandey V, Zhang M, Chong QY, et al. Hypomethylation 
associated enhanced transcription of trefoil factor-3 mediates tamoxifen-stimulated oncogenicity of ER+ endometrial carcinoma cells. Oncotarget 2017;8:77268-91.

154. Russo M, Broach J, Sheldon K, et al. Clonal evolution in paired endometrial intraepithelial neoplasia/atypical hyperplasia and endometrioid adenocarcinoma. Hum Pathol 2017;67:69-77.

155. Wang W, Li Y, Li S, et al. Pooling-Based Genome-Wide Association Study Identifies Risk Loci in the Pathogenesis of Ovarian Endometrioma in Chinese Han Women. Reprod Sci 2017;24:400-6.

156. Wu JP, Luo X. The association between murine double minute 2 (MDM2) rs2279744 and endometrial cancer risk in a Chinese Han population. Cell Mol Biol 2017;63:128-30.

157. Yildırım ME, Karakus S, Kurtulgan HK, et al. The Association of Plasminogen Activator Inhibitor Type 1 (PAI-1) Level and PAI-1 4G/5G Gene Polymorphism with the Formation and the Grade of Endometrial Cancer. Biochem Genet 2017;55:314-21.

158. Geng YH, Wang ZF, Jia YM, et al. Genetic polymorphisms in $\mathrm{CDH} 1$ are associated with endometrial carcinoma susceptibility among Chinese Han women. Oncol Lett 2018;16:6868-78.

159. Kolin DL, Dong F, Baltay M, et al. SMARCA4deficient undifferentiated uterine sarcoma (malignant rhabdoid tumor of the uterus): a clinicopathologic entity distinct from undifferentiated carcinoma. Mod Pathol 2018;31:1442-56.

160. Matsuura M, Yamaguchi K, Tamate M, et al. Efficacy of liquid-based genetic diagnosis of endometrial cancer. Cancer Sci 2018;109:4025-32.

161. Oz M, Karakus S, Yildirim M, et al. Genetic variants in the microRNA machinery gene (Dicer) have a prognostic value in the management of endometrial cancer. J Cancer Res Ther 2018;14:1279-84.

162. Reiter JG, Makohon-Moore AP, Gerold JM, et al. Minimal functional driver gene heterogeneity among untreated metastases. Science 2018;361:1033-7.

163. Smolarz B, Michalska MM, Samulak D, et al. Studies of Correlations Between Single Nucleotide Polymorphisms of DNA Repair Genes and Endometrial Cancer in Polish Women. Anticancer Res 2018;38:5223-9.

164. Soumerai TE, Donoghue MTA, Bandlamudi C, et al. Clinical Utility of Prospective Molecular Characterization in Advanced Endometrial Cancer. Clin Cancer Res 2018;24:5939-47.

165. Yang L, Zhang L, Huang Q, et al. Combination of Scoring Criteria and Whole Exome Sequencing Analysis of
Synchronous Endometrial and Ovarian Carcinomas. Int J Gynecol Cancer 2018;28:704-12.

166. Yoshimoto M, Tokuda A, Nishiwaki K, et al. Abnormal Expression of PICT-1 and Its Codon 389 Polymorphism Is a Risk Factor for Human Endometrial Cancer. Oncology 2018;95:43-51.

167. You D, Wang Y, Zhang Y, et al. Association of Foxp3 promoter polymorphisms with susceptibility to endometrial cancer in the Chinese Han women. Medicine 2018;97:e0582.

168. Brooks RA, Tritchler DS, Darcy KM, et al. GOG 8020/210: Risk stratification of lymph node metastasis, disease progression and survival using single nucleotide polymorphisms in endometrial cancer: An NRG oncology/ gynecologic oncology group study. Gynecol Oncol 2019;153:335-42.

169. Buchynska LG, Brieieva OV, Iurchenko NP. Assessment of HER-2/neu, small es, Cyrillic-MYC and CCNE1 gene copy number variations and protein expression in endometrial carcinomas. Exp Oncol 2019;41:138-43.

170. Cai J, Cui K, Niu F, et al. Genetics of IL6 polymorphisms: Case-control study of the risk of endometrial cancer. Mol Genet Genomic Med 2019;7:e00600.

171.de Jonge MM, Auguste A, van Wijk LM, et al. Frequent Homologous Recombination Deficiency in Highgrade Endometrial Carcinomas. Clin Cancer Res 2019;25:1087-97.

172. Dong F, Costigan DC, Howitt BE. Targeted nextgeneration sequencing in the detection of mismatch repair deficiency in endometrial cancers. Mod Pathol 2019;32:252-7.

173. Gotoh O, Sugiyama Y, Takazawa Y, et al. Clinically relevant molecular subtypes and genomic alterationindependent differentiation in gynecologic carcinosarcoma. Nat Commun 2019;10:4965.

174. Hájková N, Ticha I, Hojny J, et al. Synchronous endometrioid endometrial and ovarian carcinomas are biologically related: A clinico-pathological and molecular (next generation sequencing) study of 22 cases. Oncol Lett 2019;17:2207-14.

175.Huang CY, Liao KW, Chou CH, et al. Pilot Study to Establish a Novel Five-Gene Biomarker Panel for Predicting Lymph Node Metastasis in Patients With Early Stage Endometrial Cancer. Front Oncol 2020;9:1508.

176. Inoue S, Hirota Y, Ueno T, et al. Uterine adenomyosis is an oligoclonal disorder associated with KRAS mutations. Nat Commun 2019;10:5785.

177.Liu T, Jiang L, Yu L, et al. Association of TNFAIP8 gene 
polymorphisms with endometrial cancer in northern Chinese women. Cancer Cell Int 2019;19:105.

178. Ozgor BY, Iyibozkurt C, Bastu E, et al. Investigation of resistin 420 and 62 gene polymorphism in patients with endometrial cancer. Taiwan J Obstet Gynecol 2019;58:164-7.

179. Tekin L, Edgunlu T, Celik SK. Lack of association between sirtuin gene variants and endometrial cancer. Meta Gene 2019;19:56-9.

180. Wu J, Zhang W, Cai J, et al. Influence of IL-1R2 polymorphisms on endometrial cancer susceptibility in the Chinese Han population. Mol Genet Genomic Med 2019;7:e650.

181. Wujcicka W, Zajac A, Stachowiak G. Impact of MDM2, TP53 and P14ARF Polymorphisms on Endometrial Cancer Risk and Onset. In Vivo 2019;33:917-24.

182. Casas-Arozamena C, Diaz E, Moiola CP, et al. Genomic Profiling of Uterine Aspirates and cfDNA as an Integrative
Liquid Biopsy Strategy in Endometrial Cancer. J Clin Med 2020;9:585.

183. Kolin DL, Quick CM, Dong F, et al. SMARCA4-deficient Uterine Sarcoma and Undifferentiated Endometrial Carcinoma Are Distinct Clinicopathologic Entities. Am J Surg Pathol 2020;44:263-70.

184. Liu Y, Sun Y, Wu J, et al. Polymorphisms in IL-1A are associated with endometrial cancer susceptibility among Chinese Han population: A case-control study. Int J Immunogenet 2020;47:169-74.

185.O'Hara AJ, Le Gallo M, Rudd ML, et al. High-resolution copy number analysis of clear cell endometrial carcinoma. Cancer Genet 2020;240:5-14.

186. Wujcicka W, Zajac A, Szyllo K, et al. Association of SNPs in CDKN2A (P14ARF) Tumour Suppressor Gene with Endometrial Cancer in Postmenopausal Women. In Vivo 2020;34:943-51. 